\title{
EFFECT OF SITOFEX (CPPU) ON FRUIT SET, FRUIT QUALITY OF ANNA APLLE TREES
}

Fatma I. I. Abou Grah, Abd El-Megeed Nagwa and El-Shereif $\mathrm{H}$.

Hort. Res. Institute, Agric. Res. Center Giza. Egypt .

ABSTRACT

Efficiency of the synthetic cytokinin (CPPU) (N- (2-chloro-4pytidyle-N-phenylurea) was studied on Anna apple trees at full bloom, 14 days after full bloom and two time spraying (at full bloom and 14 days after full bloom). CPPU tended significantly to increase the percentage of fruit set, yield and fruiting, while it decreased fruit drop of all treatments. The best results were obtained by $20 \mathrm{ppm}$ CPPU at full bloom and $10 \mathrm{ppm}$ CPPU two time spraying in the first season. While, the $15 \mathrm{pm}$ CPPU at full bloom was the best during the second season.

Highest fruit weight, fruit size and fruit dimensions were obtained by $15 \mathrm{ppm}$ concentrations at 14 days after full bloom in the two seasons. Concerning fruit shape index (L/D), an increase in fruit diameter than its length due to all conducted CPPU treatments in both seasons. As well as, acidity and TSS/acid ratio were significantly improved as a result of all studied treatments when compared to the control.

It could be concluded that, most of studied treatments resulted in a positive and significant effect on most studied characteristics, since (CPPU at $15 \mathrm{ppm}$ at full bloom and $20 \mathrm{ppm}$ at 14 days after full bloom were the most effective treatments for increasing fruit set and yield as well as improving the most fruit properties.

Key words: Cytokinin (CPPU), Anna apple trees, Fruit set and Fruit drop

\section{INTRODUCTION}

Apple is considered one of the major and the most important deciduous fruit trees in Egypt. Many investigators reported that, yield and quality of Anna apple fruits depended upon several factors, one of the most vital factor which affects and plays an important role in this concern is spraying with some growth regulators which enhance fruit set, reduce fruit drop, consequently increase productivity. Moreover, both concentration and date of application are very important factors which in true reflect in increasing and improving fruit yield and fruit characteristics.

Several investigations mentioned that, spraying deciduous fruit trees with Sitofex (CPPU) different concentrations enhanced cell division, increased cell size, increased fruit weight, size and fruit yield. Furthermore, application of the abovementioned growth regulators improved the most fruit properties. Nickell (1986), Rizk (1998), Feng et al., (1999), Al-Ashkar (2000) Ranpise et al., (2000) and Marwad (2001) on grapes; El-Barkooky (1985), Greene (1989) and Khurshid et al., (1997), on apple; Biasl et al., (1991) and Lowes and Woolley (1992) on kiwi; Jindal and Sharma (1986) on plum; Kabeel (1999) on persimmon; Kabeel and Fawaaz (2005) on pear.

Due to the little information currently available about the effect of CPPU on apple fruit, this study was carried out to explore the effect of concentration and application time of CPPU on apple, fruit set, drop and quality.

Fayoum J. Agric. Res. \& Dev., Vol.23, No.1,(B). January, 2009 


\section{MATERIAL AND METHODS}

The current investigation was under taken in the experimental farm at El-Kanater, Horticultural Research Station, Kalyubia, Governorate, Egypt. This study has been extended for the two consecutive seasons of 2007 and 2008 on 10- year-old-apple trees. Anna apple trees were budded on Malling Maritton 106 rootstock, planted at 2.5 meters apart and grown in clay loamy soils. Selected trees were healthy, nearly uniform as possible in their vigour and subjected to the similar fertilization, irrigation, pruning and pest control programs usually done at this region.

Different foliar sprays with Sitofex (CPPU) treatments used in this study were as follows:

1- CPPU at $5 \mathrm{ppm}$.

2- CPPU at $10 \mathrm{ppm}$

3- CPPU at $15 \mathrm{ppm}$

4- CPPU at $20 \mathrm{ppm}$

5- Control

These treatments were sprayed at: a) Full bloom stage, b) At full bloom and two weeks after full bloom and c) Two weeks after full bloom.

Forty five trees were devoted and complete randomized design was used, since each treatment was replicated by a two trees. Four main branches well distributed around the periphery of tree (one branch on each direction) were tagged and the following measurements were determined:

\section{1- Fruiting measurements:}

1-a. Percentages of fruit set and fruit drop:

Both number of flowers and set fruitlets on the tagged branches were counted and recorded for all treatments, then percentage of fruit set was calculated by the following equation according to Westwood (1978)

Number of set fruitlets

(\%) Fruit set $=$

No. of opened flowers

Furthermore, number of dropped fruits were recorded till harvest time, then estimated as percentage on the basis of initial number of fruitlets according to this equation:

(\%) Fruit drop $=\frac{\text { Number of dropped fruits }}{\text { Number of set fruitlets }} \times 100$

1-b. Yield and percentage of yield increment than control:

The average of tree yield in $\mathrm{kgs}$ for each treatment was determined at harvest time (at maturity stage). Furthermore, the yield increment percentage for each treatment as compared to the control was estimated according to the following equation:

$$
(\%) \text { Yield incr. }=\frac{\text { Yield } / \text { treatment }- \text { yield / control }}{\text { Yield / control }} \times 100
$$

At picking date, number of fruits/tree were used to calculate yield monetary value $=$ Fruit yield $(\mathrm{kg}) /$ tree $\mathrm{x}$ farm - gate price $($ L.E.1.5) .

\section{2- Fruit quality:}

At the time of harvest (at maturity stage), ten fruits from each replicate were randomly sampled and the following fruit characteristics were determined including average fruit weight (gm.), fruit firmness ( $\mathrm{lb} / \mathrm{inch} 2)$ using a Magness and Tayler pressure tester with $7 / 18$ inch plunger. Furthermore, fruit chemical

Fayoum J. Agric. Res. \& Dev., Vol.23, No.1,(B). January, 2009 
EFFECT OF SITOFEX (CPPU) ON FRUIT SET, FRUIT QUALITY... 56

properties were also determined including the average fruit juice TSS percentage using handy refactometer, fruit juice acidity percentage as malic acid (mgs/100 gms fruit juice) according to A.O.A.C. (1985) and Vogel (1968), TSS/acid ratio was calculated.

All the obtained data were statistically analyzed of variance method according to Snedecor and Cochran (1990) using L.S.D. values at $0.5 \%$ level. However, means were compared according to Duncan`s multiple range test (Duncan, 1955).

\section{RESULTS AND DISCUSSION}

\section{Fruiting measurements:}

1-a. Percentages of fruit set and fruit drop:

Data in Table (1) displayed clearly that, all treatment sprays resulted in a significant increase in fruit set \% as compared to the control. Moreover, trees sprayed with $20 \mathrm{ppm}$ concentration of CPPU were statistically the superior as exhibited significantly the highest value fruit set $(18.59 \%)$. Meanwhile, the opposite trend was observed with the control which was statistically the inferior as exhibited the least value of fruit set $(11.58 \%)$. On the other hand, the best time to treat spraying was at full bloom and after two weeks $(15.72 \%$ and 20.71) this result was detected during both 2007 and 2008 seasons. In additions, the best interaction in this respect was obtained by $20 \mathrm{ppm}$ concentration of CPPU with the two time applications during 2007 and 2008 seasons, respectively (22.5 and $26.87 \%)$.

With regard to the percentage of fruit drop, data in the same Table showed obvious trend where all treatment concentrations under study decreased significantly percentage of fruit drop as compared to the control in the two experimental seasons. Data pointed out that, the highest percentage of fruit drop was always concomitant to the control ( 85.5 and $80.83 \%)$ whereas either CPPU at $5 \mathrm{ppm}$ in the first season $(65.22 \%)$ and CPPU at $10 \mathrm{ppm}$ in the second season $(68.53 \%)$ were the most effective treatments regarding reducing fruit drop. Since they resulted in statistically the lowest values in this concern.

On the other hand, the application time after two weeks of full bloom had the least value of fruit drop (70.19 and $68.15 \%)$ during the two seasons. Whereas either CPPU at $20 \mathrm{ppm}$ or at $10 \mathrm{ppm}$ application after two weeks of full bloom or the two application (at full bloom and after two weeks) were the most effective treatments regarding reducing of fruit drop. The obtained results are in conformity with those previously reported by Nickell (1986) and Feng $\boldsymbol{e t}$ al., (1999) on grapes, El-Barkouky (1985) and Khurshid et al., (1997) on apple; Kabeel (1999) on persimmon, Guirguis et al., (2003) and Kabeel and Fawaaz (2005) on pear trees.

Fayoum J. Agric. Res. \& Dev., Vol.23, No.1,(B). January, 2009 
Fatma I. I. Abou Grah, et al.

Table (1): Effect of Sitofex spray at different concentrations (A) and at different dates $(B)$ on percentage of fruit set and fruit drop.

\begin{tabular}{|c|c|c|c|c|c|c|c|c|}
\hline \multicolumn{9}{|c|}{2007 season } \\
\hline \multirow{2}{*}{$\begin{array}{c}\text { Date } \\
\text { Treat }\end{array}$} & \multicolumn{4}{|c|}{ Fruit set (\%) } & \multicolumn{4}{|c|}{ Fruit drop (\%) } \\
\hline & $\mathrm{A}^{*}$ & B & $\mathrm{C}$ & Ave.(A) & $\mathrm{A}$ & $\mathrm{B}$ & $\mathrm{C}$ & \begin{tabular}{|l} 
Ave. (A) \\
\end{tabular} \\
\hline $5 \mathrm{ppm}$ & $13.33 \mathrm{~d}-\mathrm{f}$ & $13.37 \mathrm{ef}$ & $11.83 \mathrm{ef}$ & $12.84 \mathrm{D}$ & $54.50 \mathrm{f}$ & $67.83 \mathrm{de}$ & $73.33 \mathrm{~cd}$ & 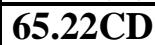 \\
\hline 10 ppm & $16.67 \mathrm{c}$ & $15.07 \mathrm{c}-\mathrm{e}$ & $13.00 \mathrm{~d}-\mathrm{f}$ & 14.91C & $74.23 \mathrm{~cd}$ & $76.27 b c$ & $66.70 \mathrm{e}$ & 72.48B \\
\hline 15 ppm & $12.87 d-f$ & $16.93 \mathrm{bc}$ & $20.00 \mathrm{~b}$ & $16.60 \mathrm{~B}$ & $78.23 b c$ & $79.23 b c$ & 68.90de & 75.46B \\
\hline 20 ppm & $17.20 \mathrm{bc}$ & $22.50 \mathrm{a}$ & $16.07 \mathrm{~cd}$ & $18.59 \mathrm{~A}$ & $81.63 \mathrm{ab}$ & $73.67 \mathrm{~cd}$ & $55.03 \mathrm{f}$ & 70.11C \\
\hline Control & $12.67 \mathrm{ef}$ & $10.73 \mathrm{f}$ & $11.33 \mathrm{f}$ & $11.58 \mathrm{E}$ & $82.23 \mathrm{ab}$ & $87.33 a$ & $86.97 \mathrm{a}$ & $85.50 \mathrm{~A}$ \\
\hline Ave. (B) & 14.55B & $15.72 \mathrm{~A}$ & $14.45 B$ & & 74.17B & $76.87 \mathrm{~A}$ & $70.19 \mathrm{C}$ & \\
\hline \multicolumn{9}{|c|}{2008 season } \\
\hline $5 \mathrm{ppm}$ & $20.70 b$ & $22.43 b$ & $15.87 \mathrm{c}$ & $\mid 19.67 A$ & $77.20 \mathrm{bc}$ & $71.83 \mathrm{~cd}$ & $72.33 \mathrm{~cd}$ & 73.79B \\
\hline 10 ppm & $14.57 \mathrm{ed}$ & $21.00 \mathrm{~b}$ & $10.63 \mathrm{e}$ & $15.40 \mathrm{C}$ & $76.20 \mathrm{c}$ & $63.80 \mathrm{e}$ & $65.60 \mathrm{e}$ & 68.53C \\
\hline 15 ppm & $15.13 \mathrm{ed}$ & $21.70 \mathrm{~b}$ & $20.33 b$ & $19.05 B$ & $77.33 \mathrm{bc}$ & $72.67 \mathrm{~cd}$ & $67.83 \mathrm{de}$ & 72.61B \\
\hline 20 ppm & $20.50 \mathrm{~b}$ & $26.87 \mathrm{a}$ & $15.17 \mathrm{~cd}$ & $20.84 \mathrm{~A}$ & $71.60 \mathrm{~cd}$ & $82.53 \mathrm{ab}$ & $62.33 \mathrm{e}$ & 72.15B \\
\hline Control & 12.60de & $11.53 \mathrm{e}$ & $10.53 \mathrm{e}$ & $11.55 \mathrm{D}$ & $84.83 \mathrm{a}$ & $85.00 \mathrm{a}$ & $72.67 \mathrm{~cd}$ & 80.83A \\
\hline Ave. (B) & $16.70 \mathrm{~B}$ & $20.71 \mathrm{~A}$ & 14.51C & & 77.43A & $75.17 \mathrm{~A}$ & 68.15B & \\
\hline
\end{tabular}

L.S.D. at $5 \%$ :

$\begin{array}{rllll}A=1.315 & 1.125 & 2.600 & \mathbf{2 . 5 2 0} \\ B=1.697 & 1.453 & \mathbf{3 . 3 5 7} & \mathbf{3 . 2 5 8} \\ \mathbf{B}=\mathbf{2 . 9 4} & \mathbf{2 . 5 1 7} & \mathbf{5 . 8 1 4} & \mathbf{5 . 6 4 9}\end{array}$

* A: Spray at full bloom.

B: Spray at full bloom and two weeks after full bloom.

C: Spray at two weeks after full bloom.

1-b. Yield and yield increment $\%$ in relation to the control:

Data tabulated in Tables ( $2 \& 3)$ clear that, both number of fruits/tree, yield/tree, yield/feddan and yield increment percentage were responded significantly to all used concentrations as compared to the control during the two studied seasons. Furthermore, the greatest statistically values of yield parameters were resulted from Anna apple trees being sprayed with CPPU at 20 ppm (450 fruits/tree, $59.27 \mathrm{~kg}$ fruits/tree, 15.53 ton fruits/feddan and $2.7 \%$ increment) followed by $15 \mathrm{ppm}, 10 \mathrm{ppm}$ and $5 \mathrm{ppm}$ treatments as compared to the control, which reflected significantly the lowest value of yield parameters (170.6 fruits/tree, $16.01 \mathrm{~kg} /$ fruits/tree, 4.29 ton fruits/feddan and $0.0 \%$ increment). On the other hand, the best results in this respect were obtained by two application time (at full bloom and after two weeks) during the two seasons. While, the lowest value were obtained by sprayed with CPPU after two weeks from full bloom. Moreover, the interaction $20 \mathrm{ppm}$ CPPU sprayed at full bloom and after two weeks was better than the other treatments.

These results are completely agreed with those being mentioned by many investigators Greene (1989) on apple, Kabeel (1999) Kabeel and Fawaaz (2005) on pear, Feng et al., (1999), Al-Ashkar (2000), Marwad (2001) on grapes.

Fayoum J. Agric. Res. \& Dev., Vol.23, No.1,(B). January, 2009 
EFFECT OF SITOFEX (CPPU) ON FRUIT SET, FRUIT QUALITY... 58

Table 2

Fayoum J. Agric. Res. \& Dev., Vol.23, No.1,(B). January, 2009 
It is also noticeable that, yield monetary value (Table 2) was parallel to the increase of CPPU concentration from $0.0 \mathrm{ppm}$ (LE 24.0), to $5 \mathrm{ppm}$ (LE 32.0) to $10 \mathrm{ppm}$ (LE 35.6) to $15 \mathrm{ppm}$ (LE 37.1) and to $20 \mathrm{ppm}$ (LE 88.9). this trend was clear throughout the two studied seasons and statistically confirmed. We can also say that CPPU sprays have better return when sprayed at full bloom and next after two weeks (LE 49.9 and 55.5) than the other treatments. However, the best interaction was $20 \mathrm{ppm}$ at full bloom and after two weeks (LE 95.4 and 82.4).

Table (3): Effect of Sitofex spray at different concentrations (A) and at different dates $(B)$ on percentage of yield increment than control and fruit yield/feddan.

\begin{tabular}{|c|c|c|c|c|c|c|c|c|}
\hline \multicolumn{9}{|c|}{2007 season } \\
\hline \multirow{2}{*}{$\begin{array}{l}\text { Date } \\
\text { Treat }\end{array}$} & \multicolumn{4}{|c|}{ Yield increment than control } & \multicolumn{4}{|c|}{ Yield/feddan (ton) } \\
\hline & $\mathrm{A}^{*}$ & $\mathrm{~B}$ & $\mathrm{C}$ & Ave. (A) & $\mathrm{A}$ & $\mathrm{B}$ & $\mathrm{C}$ & Ave. (A) \\
\hline $5 \mathrm{ppm}$ & $0.317 \mathrm{de}$ & $0.400 \mathrm{de}$ & $0.307 \mathrm{de}$ & $0.341 \mathrm{C}$ & $5.083 \mathrm{~h}$ & $5.817 \mathrm{f}-\mathrm{h}$ & $5.670 \mathrm{gh}$ & 5.52D \\
\hline $10 \mathrm{ppm}$ & $0.583 \mathrm{~d}$ & $0.613 d$ & $0.313 \mathrm{de}$ & $0.503 \mathrm{C}$ & $6.373 \mathrm{fg}$ & $6.573 \mathrm{f}$ & $5.690 \mathrm{gh}$ & $6.21 \mathrm{C}$ \\
\hline $15 \mathrm{ppm}$ & $1.363 \mathrm{c}$ & $1.487 \mathrm{c}$ & $1.333 \mathrm{c}$ & $1.394 \mathrm{~B}$ & $9.543 \mathrm{e}$ & $10.310 \mathrm{~d}$ & $10.050 \mathrm{de}$ & 9.97B \\
\hline $20 \mathrm{ppm}$ & $2.777 \mathrm{ab}$ & $3.033 \mathrm{a}$ & $2.370 \mathrm{~b}$ & 2.727A & $15.350 \mathrm{~b}$ & $16.650 \mathrm{a}$ & $14.570 \mathrm{c}$ & $15.53 \mathrm{~A}$ \\
\hline Control & $0.000 \mathrm{e}$ & $0.000 \mathrm{e}$ & $0.000 \mathrm{e}$ & $0.00 D$ & $4.223 \mathrm{i}$ & $4.327 \mathrm{i}$ & $4.323 \mathrm{i}$ & $4.29 \mathrm{E}$ \\
\hline Ave. (B) & 1.008AB & 1.107A & $0.865 B$ & & 8.11B & 8.74A & $8.06 B$ & \\
\hline \multicolumn{9}{|c|}{2008 season } \\
\hline $5 \mathrm{ppm}$ & $0.237 \mathrm{de}$ & $0.423 \mathrm{~d}$ & $0.197 \mathrm{de}$ & $0.286 \mathrm{C}$ & $5.333 \mathrm{fg}$ & $6.830 \mathrm{e}$ & $5.250 \mathrm{fg}$ & $5.81 \mathrm{D}$ \\
\hline $10 \mathrm{ppm}$ & $0.483 \mathrm{~d}$ & $0.533 \mathrm{~d}$ & $0.310 \mathrm{de}$ & $0.442 \mathrm{C}$ & $6.573 \mathrm{e}$ & $8.760 \mathrm{~d}$ & $5.770 \mathrm{ef}$ & 7.03C \\
\hline $15 \mathrm{ppm}$ & $1.317 \mathrm{c}$ & $1.907 \mathrm{ab}$ & $1.363 \mathrm{c}$ & 1.529B & $9.770 \mathrm{~cd}$ & $13.700 \mathrm{a}$ & $10.410 \mathrm{c}$ & 11.29B \\
\hline $20 \mathrm{ppm}$ & $1.917 \mathrm{ab}$ & $2.017 \mathrm{a}$ & $1.636 \mathrm{bc}$ & $1.854 \mathrm{~A}$ & $12.210 \mathrm{~b}$ & $14.340 \mathrm{a}$ & $11.580 \mathrm{~b}$ & 12.71A \\
\hline Control & $0.000 \mathrm{e}$ & $0.000 \mathrm{e}$ & $0.000 \mathrm{e}$ & 0.00D & $4.330 \mathrm{~g}$ & $4.760 \mathrm{fg}$ & $4.400 \mathrm{~g}$ & $4.50 \mathrm{E}$ \\
\hline Ave. (B) & 0.791B & 0.976A & 0.700B & & 7.64B & $9.68 \mathrm{~A}$ & 7.48B & \\
\hline
\end{tabular}

L.S.D. at $5 \%$ :

$\begin{array}{rllll}A & =0.209 & 0.148 & 0.324 & 0.497 \\ B= & 0.270 & 0.191 & 0.419 & 0.642 \\ A \times B=0.467 & 0.330 & 0.725 & 1.112\end{array}$

* A: Spray at full bloom.

B: Spray at full bloom and two weeks after full bloom.

C: Spray at two weeks after full bloom.

\section{Fruit characteristics:}

2-1. Fruit physical characteristics:

2-1-a. Fruit weight, size and firmness:

As shown in Table (4), fruit weight was increased by CPPU applications after two weeks of full bloom (117.4 and $116.4 \mathrm{~g}$ ) as compared with the other treatments $(113.2,113.3,109.6$ and 114.0 g.) through 2007 and 2008 seasons, respectively.

It is also noticeable that, fruit weight gradually and significantly increased with increasing CPPU concentration from $5 \mathrm{ppm}(104.0 \mathrm{~g}$.) to $10 \mathrm{ppm}(110.2 \mathrm{~g}$.) to $15 \mathrm{ppm}(125.3 \mathrm{~g}$.) to $20 \mathrm{ppm}(129.4 \mathrm{~g}$.) comparing to control (97.8g.).

Fayoum J. Agric. Res. \& Dev., Vol.23, No.1,(B). January, 2009 


\section{EFFECT OF SITOFEX (CPPU) ON FRUIT SET, FRUIT QUALITY... 60}

It is clear from the same Table that, foliar applications of the deferent treatments of CPPU, resulted in significant increases in fruit size. The highest value was obtained by CPPU at $20 \mathrm{ppm}\left(138.1 \mathrm{~cm}^{3}\right)$ followed by $15(125.0$ $\left.\mathrm{cm}^{3}\right), 10\left(123.3 \mathrm{~cm}^{3}\right) 5 \mathrm{ppm}\left(105.2 \mathrm{~cm}^{3}\right)$ compared to the control $\left(86.0 \mathrm{~cm}^{3}\right)$. The present data are in accordance with those mentioned by El-Barkouky (1985); Jindal and Sharma (1986); Biasl et al., (1991); Lowes and Woolley (1992); Rizk (1998); Kabeel (1999) and Guirguis et al., (2003) on some fruit deciduous trees.

Data of fruit flesh firmness in the two seasons as shown in the same Table obviously indicate that, it was significantly increased by increasing CPPU concentrations. The results also indicated that, all the after full bloom application gave higher values than the other treatments and showed a positive relation as the values increased by increasing CPPU concentrations. These results are in agreement with the fact that, at maturity, firmer fruits easily tolerate post harvest treatments. Moreover, previous reports of Khurshid et al., (1997); Kabeel (1999) and Guirguis et al., (2003) on apple, persimmon and pear trees have supported this trend.

\section{2-1-b. Fruit dimensions:}

It is clear in Table (5) that, fruit length and diameter gradually increased as CPPU concentration increased from $0.0 \mathrm{ppm}(4.76$ and $4.90 \mathrm{~cm}$.) to $5 \mathrm{ppm}(4.86$ and $5.06 \mathrm{~cm}$.) to $10 \mathrm{ppm}(5.5$ and $5.22 \mathrm{~cm}$.) to $15 \mathrm{ppm}(5.87$ and $5.60 \mathrm{~cm}$.) to $20 \mathrm{ppm}(5.97$ and $5.81 \mathrm{~cm}$.).

Meanwhile, CPPU spray was more effective when sprayed at full bloom and after two weeks $(5.57$ and $5.46 \mathrm{~cm}$.) than the other treatments. Moreover, $20 \mathrm{ppm}$ CPPU spray at full bloom and after two weeks show better interaction in this respect.

The results of the two seasons indicated that, all the CPPU treated fruits resulted in an increase in length than in diameter as all obtained shape index values were less than the control and the increase in length values has positively linked with a parallel increase in CPPU concentration. Obtained results concerning the response of fruit dimensions and fruit shape index were generally supported by finding of Nickell (1986), Biasl et al., (1991), Lowes and Woolley (1992) Kabeel (1999) and Guirguis et al., (2003) on kiwi, grapes and pear fruits.

\section{2-2. Fruit chemical properties:}

\section{2-2-a. Fruit juice TSS \%:}

Regarding the response of fruit juice TSS \% of tested treatments, data in Table (6), indicates that TSS responded significantly to the most of treatments. Moreover, the richest fruits in their content of TSS \% was achieved by trees sprayed with 5 ppm CPPU treatments (13.39 and 11.78\%). Meanwhile, juice TSS was better when CPPU sprayed after two weeks from full bloom. Meanwhile, the lowest significant values of fruit juice TSS was the interaction 10, 15 ppm CPPU applied twice (at full bloom and after two weeks).

On the other hand, total soluble solids (T.S.S.) percentage results of the first season showed that, the most CPPU treatments increased values than the control either applied after two weeks from full bloom are applied twice (at full bloom and after two weeks).

Fayoum J. Agric. Res. \& Dev., Vol.23, No.1,(B). January, 2009 
Table 4

Fayoum J. Agric. Res. \& Dev., Vol.23, No.1,(B). January, 2009 
EFFECT OF SITOFEX (CPPU) ON FRUIT SET, FRUIT QUALITY... 62

Table 5

Fayoum J. Agric. Res. \& Dev., Vol.23, No.1,(B). January, 2009 
Table 6

Fayoum J. Agric. Res. \& Dev., Vol.23, No.1,(B). January, 2009 


\section{EFFECT OF SITOFEX (CPPU) ON FRUIT SET, FRUIT QUALITY... 64}

\section{2-2-b. Fruit juice total acidity \%:}

Obtained results in Table (6) show clearly that, CPPU treatments decreased values than the control specially 5 ppm $(0.361$ and $0.351 \%$ during the two studied seasons, respectively. Moreover, CPPU spray at full bloom resulted in lower acidity (0.386 and $0.376 \%$ in 2007 and 2008 seasons, respectively) than the other treatments. However, $10 \mathrm{ppm}$ CPPU spray at full bloom consider better interaction in this respect ( 0.307 and $0.297 \%$, respectively). Meanwhile, TSS/acidity ratio did not show clear trend.

\section{CONCLUSION}

The present results of 5, 10, 15 and 20 ppm CPPU sprays at: A) full bloom, B) full bloom and after two weeks, and C) after two weeks of full bloom showed a positive effect than control. However, $20 \mathrm{ppm}$ concentration was superior where it increased percentage of fruit set, number of fruits/tree, fruit yield per tree and per feddan, yield increment than control and subsequently yield monetary value. Also $20 \mathrm{ppm}$ has a benefit effect (than the other treatments) on fruit characteristics (fruit weight, size, dimensions, fruit shape index and juice TSS). Moreover, CPPU spray at full bloom and after two weeks has better effect on the former fruit and yield attributes. So, we can recommended apple (Anna cv.) growers to spray $20 \mathrm{ppm}$ CPPU at full bloom and next after two weeks to increase the yield, fruit quality and yield monetary value.

\section{REFERENCES}

Al-Ashkar, R.A. (2000). Effect on some $\mathrm{GA}_{3}$ and CPPU treatments on yield and fruit quality of Ruby seedless and Flame seedless grapes. Egy. J. Appl. Sci., 15 (7): 491-510.

Association of Official Agriculture Chemists A.O.A.C. (1985). "Official Methods of Analysis" Benjamin Franklin Station, Washington D.C. U.S.A., 495-510.

Biasl, R.; G. Costa; R. Glulioni; F. Sacci and S. Sansavini (1991). Effects of CPPU on kiwi fruit performance. Acta. Hort., 297, 367-373.

Duncan, D.B. (1955): Multiple range and multiple F. tests. Biometrics, 11: 1-42.

El-Barkouky, F.M.Z. (1985). Effect of some growth regulators on flowering fruit setting and fruit quality of apple. Ph. D. Thesis Fac. of Agric. Ain Shams Univ.

Feng, X.H.; H.F. Song; Y.M. Qian and G.J. Liu (1999). Effect of treatment with CPPU and GA3 after flowering on the production and berry quality of kyoga grapes. South china fruits, 28: 2, 41. (C.F. comp. Research).

Greene, D.W. (1989). CPPU influences "Mcintish" apple crop load and fruit characteristics. Hort. Scienc, 24, 94-96.

Guirguis, N, S.; E. S. Attala and M.M. Ali (2003). Effect of sitofex (CPPU) on fruit set, fruit quality of "Le-Conte" pear cultivar. Annals of Agric. Sci. Moshtohor, 41 (1): 271-282.

Jindal, K.K. and N.S. Sharma (1986). Effect of some growth retardants in combination with nutrients on fruit maturity and quality of Japanese plum (Prunus salicina lindl) cv. Santa Rosa. Advances in research on Temperate fruits proceedings of the National Symposium on Temperate Fruits 15-18 March (1984). Hemichall Pradesh Agricultural University, Sloan, India, 281-285, 14 ref.

Kabeel, H. (1999). Effect of some growth regulators on fruit set, yield and fruit quality of "Costata" persimmon trees, Minufiya Jour. Agric. Res., 24 (5): 1727-1739.

Fayoum J. Agric. Res. \& Dev., Vol.23, No.1,(B). January, 2009 
Kabeel, H. and S.A.A. Fawaaz (2005). Effect of spraying some growth regulators on "Le-Conte" pear trees on I- productivity, fruit quality and leaf mineral content. Hort. Res. Inst, Agric. Res. Cen., Giza, Egypt., 3 (3): 173-193.

Khurished, T.; D.J.Mc. Neiland and M.C. Trought (1997). Effect of foliar applied gibberellins and soil applied paclobutrazol on reproductive and vegetative growth of "Braebun" apple trees growing under a high density planting system. New Zealand Jour. Of Crop and Hort. Sci., Lincoh Univ. (C.F. Hort. Abst. 67-6637).

Lowes, G. S. and Woolley, D. J. (1992). A new way to grow bigger kiwi fruit. Department of plant science, Marsey University, April. The Orchardist pp. 35-37.

Marwad, I.A. (2001). Effect of some sitofex (CPPU) and gibberellin $\left(\mathrm{GA}_{3}\right)$ treatments on yield fruit quality of Thompson seedless grapes. Egy. J. Appl. Sci.; 16 (10): 210-232.

Nickell, L.G. (1986). Effects of N (2-chloro-4-pyridyl- (N-phenylurea) on grapes and other crops. Proc. of Plant Growth Regulator Society of America. 13: 236-241.

Ranpise, S.A.; B.T. Pat. L and T.K. Ghure (2000). Effect of 4-chloro fernuron (CPPU) and gibberellic acid on physiochemical properties of Thompson seedless grapes. Journal of Maharashtra, India, No. 526: 293-299.

Rizk, M.H. (1998). Effect of sitofex (CPPU), $\mathrm{GA}_{3}$ and hand thinning yield and fruit quality of Thompson seedless grapes. J. Agric. Sci. Mansoura Univ., Egypt. 23 (1): 397-404.

Snedecor, G.W. and W.G. Cochran (1990): "Statistical Methods". $7^{\text {th }}$ ed., Iowa State Univ. Press Amer. Iowa, USA pp.85-86.

Vogel, A. (1968): A Text Book of Quantitative Inorganic Analysis. Longmans, New York, pp. 1216.

Westwood, M.N. (1978): Temperate Zone Pomology W. H. Freeman and Company. San Francisco.

$$
\begin{aligned}
& \text { تأثير السيتوفكس CPPU على عقد ومحصول وجودة ثمار التفاح صنف آنا }
\end{aligned}
$$

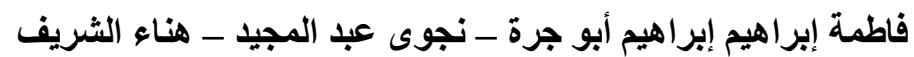

$$
\begin{aligned}
& \text { معهد بحوث البساتين - مركز البحوث الزبور البجاعية }
\end{aligned}
$$

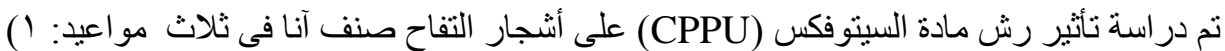

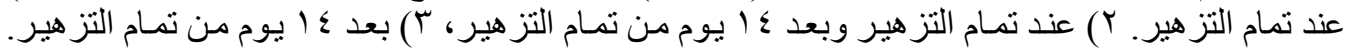

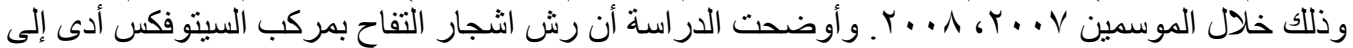

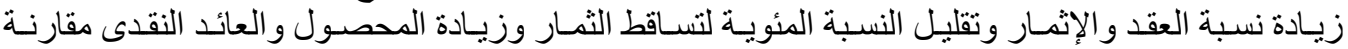

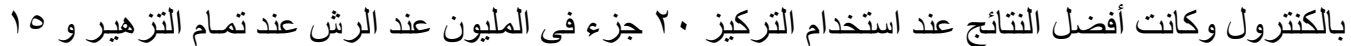

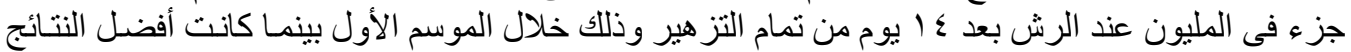

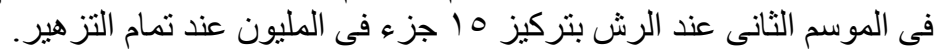

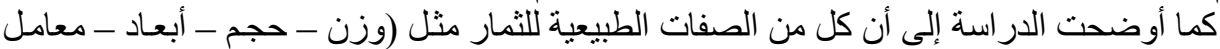

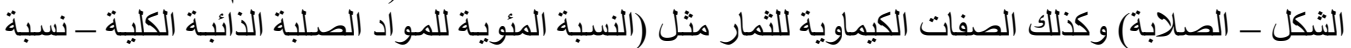

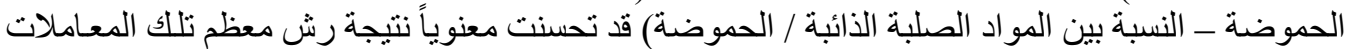

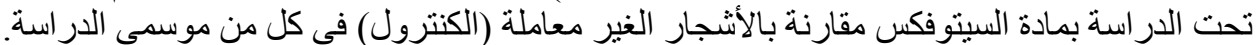

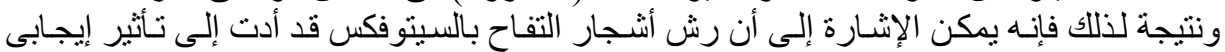

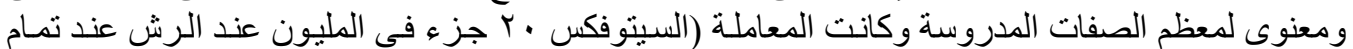

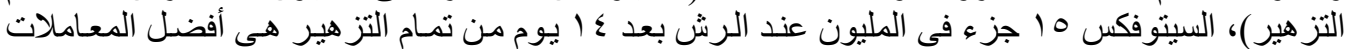

$$
\begin{aligned}
& \text { فاعلية فى زيادة عقد الثمار و المحصول وكذلك اللك تحسين معظم صفات الثمار الطبيعية و الكيماوية. }
\end{aligned}
$$

Fayoum J. Agric. Res. \& Dev., Vol.23, No.1,(B). January, 2009 